\title{
Pengaruh penambahan pati tapioka terhadap sifat mekanis dan struktur komposit high density polyethylene
}

\author{
Effect of tapioca starch addition on the mechanical properties and \\ structure of high density polyethylene composite
}

\author{
Dwi Wahini Nurhajati*, Ihda Novia Indrajati, Hesty Eka Mayasari, \\ Muhammad Sholeh
Balai Besar Kulit, Karet dan Plastik, J1. Sokonandi No. 9 Yogyakarta 55166, Indonesia *Penulis korespondensi. Telp. (0274) 512929, Faks. (0274) 563655
E-mail: dwiwahininurhajati@gmail.com

Diterima: 27 Agustus 2018

Direvisi: 6 November 2018

Disetujui: 6 November 2018

\begin{abstract}
The effect of adding tapioca starch on the mechanical properties and structure of high density polyethylene (HDPE) plastic composites was investigated. Tapioca starch filled HDPE composites were prepared using a Haake Rheomix internal mixer at $130^{\circ} \mathrm{C}$ and a rotor speed of $40 \mathrm{rpm}$ for 15 minutes. Tapioca starch were processed in the presence of glycerol, water and acetic acid. The amount of starch in HDPE composites were varied 30, 40, 50,60, and 70\%. The addition of tapioca starch reduced the tensile strength but increased the elongation at break and density of the composites. Aging treatment of HDPE composites containing tapioca starch $\geq 50 \%$ increased tensile strength but decreased the elongation at break. XRD diffractogram of HDPE composites showed that the addition of tapioca starch caused a shift in 2-theta values and decreased intensity. FTIR spectra of tapioca starch filled HDPE composites showed a shift in wavelength which was indicated to be an amorphous-crystal transition.
\end{abstract}

Keywords: Composite, HDPE, mechanical properties, tapioca starch, XRD

\begin{abstract}
ABSTRAK
Telah dilakukan penelitian tentang pengaruh penambahan pati tapioka terhadap sifat mekanis dan struktur komposit plastik high density polyethylene (HDPE). Komposit HDPE berisi pati tapioka dibuat menggunakan internal mixer Haake Rheomix pada suhu $130^{\circ} \mathrm{C}$ dan kecepatan rotor $40 \mathrm{rpm}$ selama 15 menit. Pati tapioka sebelum dibuat komposit dicampur lebih dulu dengan gliserol, air dan asam asetat. Jumlah pati di dalam komposit HDPE divariasi 30, 40, 50, 60, dan 70\%. Penambahan pati tapioka menurunkan sifat kuat tarik namun meningkatkan nilai perpanjangan putus dan densitas komposit HDPE. Perlakuan aging terhadap komposit HDPE yang berisi pati tapioka $\geq 50 \%$ menaikkan sifat kuat tarik namun menurunkan sifat perpanjangan putusnya. Difraktogram XRD komposit HDPE memperlihatkan bahwa penambahan pati tapioka menyebabkan terjadinya pergeseran nilai 2-theta dan penurunan intensitasnya. Spektra FTIR komposit HDPE yang berisi pati tapioka memperlihatkan pergeseran panjang gelombang yang diduga terjadinya transisi amorf-kristal.
\end{abstract}

Kata kunci: HDPE, komposit, pati tapioka, sifat mekanis, XRD

\section{PENDAHULUAN}

High-density polyethylene (HDPE) adalah salah satu jenis plastik polietilena yang umum dan murah digunakan untuk kemasan makanan (Tajeddin \& Abdulah, 2010), selain itu juga untuk tas belanja dan produk lainnya. Menurut
Asosiasi Industri Olefin, Aromatik dan Plastik Indonesia (Inaplas), kapasitas produksi tas kresek dari HDPE di Indonesia mencapai 300.000 ton per tahun. HDPE memiliki sifat bahan yang kuat, keras, buram dan lebih tahan terhadap suhu tinggi namun tidak dapat terurai 
oleh mikroba bila dibuang ke lingkungan. Oleh karena itu, banyak peneliti yang melakukan penggantian sebagian atau seluruh plastik polietilen dengan biomaterial yang murah seperti pati tapioka yang ketersediaannya di Indonesia cukup melimpah.

Pati tapioka sebagai biomaterial mempunyai kelemahan dibandingkan dengan polimer sintetik seperti polietilen, yaitu sifat mekanis kurang baik dan penyerapan airnya tinggi. Kelemahan ini dapat diperbaiki dengan pemberian bahan pemlastis (plasticizer). Plasticizer yang banyak digunakan adalah campuran air dan gliserol (Adamu et al., 2017; Lutfi et al., 2017; Mendes et al., 2016; Maran et al., 2014). Pencampuran antara pati yang bersifat hidrofilik dan HDPE yang bersifat hidrofobik memerlukan penambahan compatibilizer. Compatibilizer yang banyak digunakan untuk pencampuran pati dengan plastik polietilena adalah maleic anhydride grafted polyethylene (PE-g-MA) (Obashi \& Igwe, 2014; Samper-Madrigal et al., 2015; Sabetzadeh et al., 2015; Oragwu, 2016).

Penelitian terkait penggunaan pati tapioka untuk membuat plastik biodegradable umumnya menggunakan plastik polipropilen (PP) (Obasi \& Igwe, 2014), low-density polyethylene (Tanetrungroj \& Prachayawarakorn, 2015; Nguyen et al., 2016), polyvinyl alcohol (Zanela et al., 2016) dan belum banyak laporan terkait pencampuran tapioka dengan HDPE sehingga terlalu sedikit pendalaman terhadap sifat mekanis dan struktur kompositnya. Oleh karena itu, fokus penelitian adalah untuk mempelajari pengaruh penambahan pati tapioka maksimum hingga $70 \%$ terhadap sifat komposit HDPE dan bagaimana dengan struktur polimernya.

\section{BAHAN DAN METODE Bahan Penelitian}

Bahan yang digunakan dalam penelitian ini adalah resin HDPE Asrene SF 5007 buatan PT Chandra Asri (extrusion grade, densitas 0,950 $\mathrm{g} / \mathrm{cm}^{3}$ dan melt index $0,05 \mathrm{~g} / 10$ menit $\left.\left(190^{\circ} \mathrm{C} / 2,16 \mathrm{~kg}\right)\right)$, tepung tapioka merek Orang Tani buatan PT. CBSA Bogor, compatibilizer PE-g-MA dari Sigma-Aldrich, antioksidan Songnox 1010 buatan Songwon International AG, aquadest, asam stearat, dan gliserol diperoleh dari toko kimia Bratachem.

\section{Peralatan Penelitian}

Alat yang digunakan dalam penelitian ini meliputi alat proses dan alat uji yaitu Haake
Rheomix OS, hydraulic press, universal testing machine (UTM) merek Tinius Olsen-H25K, hardness tester merek Toyoseiki (Durometer D), electron densimeter EW-200SG merek Mirage, melt flow index (MFI) merek Tinius Olsen-MP 1200, spektrofotometer fourier transform infrared (FTIR) merek Shimadzu-Prestige 21, dan $X$-ray difraction (XRD) merek Rigaku miniflex 600 .

\section{Metode Penelitian \\ Pembuatan komposit}

Pati tapioka sebelum dibuat komposit dicampur dulu dengan gliserol, air dan asam asetat dengan komposisi $70 \%$ pati tapioka, $20 \%$ gliserol, $8,7 \%$ air dan 1,3\% asam asetat. Bahan tersebut semuanya dicampur dan diaduk sampai homogen selama 15 menit. Campuran tersebut kemudian disimpan 2 hari untuk memberi kesempatan bahan tambahan tersebut masuk ke dalam granula pati. Pati tapioka selanjutnya dicampur dengan HDPE di dalam sebuah alat pencampur batch Haake Rheomix OS pada suhu $130^{\circ} \mathrm{C}$ dan kecepatan rotor $40 \mathrm{rpm}$ selama 15 menit. Jumlah pati yang ditambahkan ke resin HDPE divariasi yaitu 30, 40, 50, 60, dan $70 \%$ dari jumlah resin HDPE. Bahan aditif lain yang ditambahkan adalah compatibilizer PE-g-MA (5 phr), antioksidan (1 phr) dan asam stearat (5 phr).

\section{Pengujian}

Pengujian sifat mekanis komposit meliputi kuat tarik, perpanjangan putus dan densitas. Uji kuat tarik dan perpanjangan putus mengacu ISO 527-3 dengan cuplikan bentuk dumbbell tipe 5 sebelum dan setelah pengusangan dipercepat (aging) menggunakan alat uji UTM merek Tinius Olsen-H25K. Aging dilakukan sesuai dengan metode yang ditetapkan pada ISO 188, dilakukan pada suhu $70^{\circ} \mathrm{C} \pm 2^{\circ} \mathrm{C}$ selama 168 jam \pm 2 jam. Uji densitas mengacu ISO 1183-1:2012 metode A menggunakan electron densimeter EW-200SG merek Mirage. Struktur komposit dilakukan dengan karakterisasi gugus fungsi menggunakan spektrofotometer FTIR dan pengujian kristalinitas menggunakan alat XRD.

\section{HASIL DAN PEMBAHASAN Sifat Mekanis}

Sifat mekanis komposit HDPE yang diuji meliputi sifat kuat tarik dan perpanjangan putus sebelum dan setelah aging, serta densitas. Pengaruh penambahan pati tapioka terhadap sifat 
kuat tarik dan perpanjangan putus komposit HDPE sebelum dan setelah aging disajikan pada Gambar 1 dan Gambar 2.

Gambar 1 memperlihatkan nilai rata-rata kuat tarik turun dengan meningkatnya jumlah pati tapioka. Kuat tarik tertinggi $\left(166 \mathrm{~kg} / \mathrm{cm}^{2}\right)$ dan terendah $\left(80,7 \quad \mathrm{~kg} / \mathrm{cm}^{2}\right)$ berturut-turut diperlihatkan oleh komposit yang berisi pati tapioka $30 \%$ dan $70 \%$. Hal tersebut menunjukkan bahwa semakin banyak molekul pati tapioka yang dapat menempati ruang antarmolekul rantai HDPE maka interaksi bahan pengisi pati dengan pati menjadi lebih signifikan daripada interaksi pati dengan HDPE sebagai matriks, akibatnya bila terkena tarikan menyebabkan mudah putus. Penyebab lain adalah kurangnya pembentukan ikatan antar muka yang kuat seperti ikatan hidrogen antara bahan pengisi pati dan matriks HDPE. Hasil yang sama juga didapat oleh Ali et al. (2013), Yamak (2016), Roy et al. (2015), dan Sanyang et al. (2015), yang menyatakan bahwa kekuatan tarik komposit cenderung menurun dengan penambahan pati.

Pada penelitian ini juga dilakukan uji pengusangan (aging) pada suhu $70^{\circ} \mathrm{C} \pm 2^{\circ} \mathrm{C}$ selama 168 jam \pm 2 jam. Pada umumnya aging menyebabkan penurunan sifat mekanis. Perubahan suhu akan mempengaruhi ikatan sekunder yang mengikat molekul HDPE dengan molekul bahan aditif seperti molekul pati dan plasticizer. Namun dari Gambar 1 terlihat bahwa ada beberapa komposit yang mengalami kenaikan sifat kuat tarik yaitu komposit yang berisi pati tapioka $50 \%$ (naik 6,56\%), 60\% (naik 9,52\%) dan 70\% (naik 8,55\%). Peningkatan ini mungkin karena penghilangan kandungan air yang ada di pati tapioka dari sampel komposit yang menyebabkan ikatan antara matriks HDPE dan pati lebih diperkuat. Selanjutnya, hasil penelitian ini juga didukung oleh penelitian yang dilakukan oleh Pg Adnan \& Arshad (2017), yang menyatakan bahwa perlakuan panas lebih lanjut meningkatkan sifat kuat tarik dari komposit pati tapioka yang diisi dengan abu sekam padi.

Gambar 2 memperlihatkan nilai perpanjangan putus komposit naik dengan meningkatnya jumlah pati tapioka. Perpanjangan putus tertinggi $(13,7 \%)$ dan terendah $(8,88 \%)$ berturut-turut dihasilkan oleh komposit yang yang berisi pati tapioka $70 \%$ dan 30\%. Hasil yang sama juga dilaporkan oleh Ali et al. (2013) yang menyatakan peningkatan jumlah pati tapioka meningkatkan keuletan contoh uji.

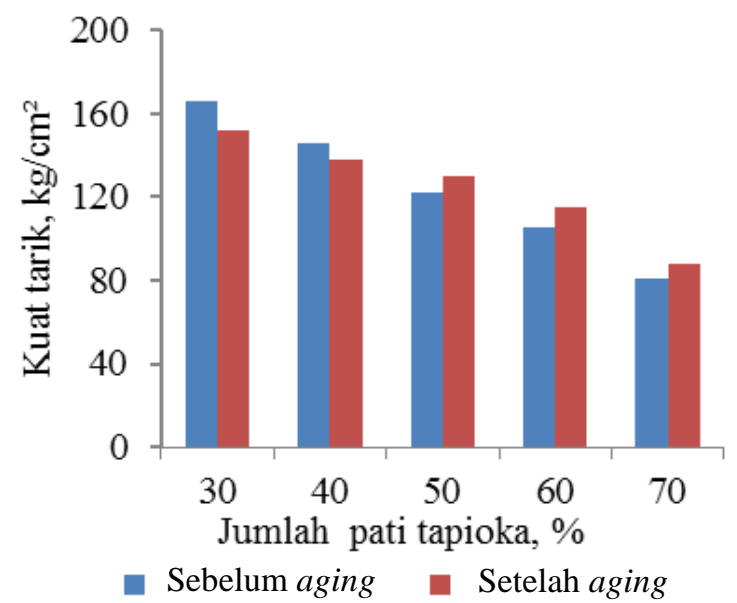

Gambar 1. Pengaruh jumlah pati tapioka terhadap sifat kuat tarik komposit HDPE.

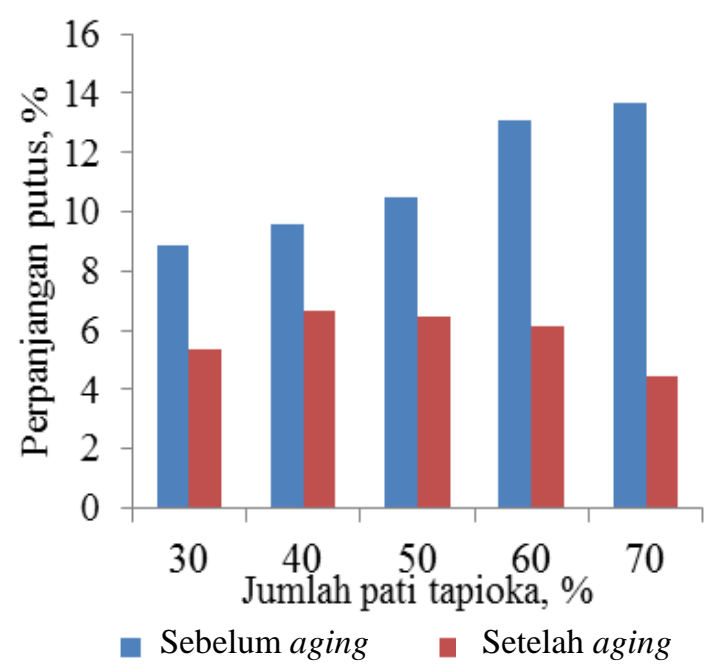

Gambar 2. Pengaruh jumlah pati tapioka terhadap sifat perpanjangan putus komposit HDPE.

Pati tapioka yang digunakan dalam penelitian ini adalah pati tapioka yang telah dicampur dengan gliserol, air dan asam asetat. Menurut Prabha \& Ranganathan (2017), adanya asam asetat meningkatkan kelarutan pati sehingga menaikkan perpanjangan putus. Gambar 2 juga memperlihatkan bahwa perpanjangan putus komposit HDPE menurun setelah dilakukan uji pengusangan (aging) pada suhu $70^{\circ} \mathrm{C} \pm 2^{\circ} \mathrm{C}$ selama 168 jam \pm 2 jam. Penurunan sifat perpanjangan putus komposit naik dengan meningkatnya jumlah pati tapioka. Penurunan sifat perpanjangan putus tertinggi $(67,81 \%)$ diperlihatkan oleh komposit yang berisi pati tapioka $70 \%$. Penurunan perpanjangan putus ini mungkin karena penghilangan kandungan air yang terdapat pada pati tapioka 
dari sampel komposit yang menyebabkan ikatan antara matriks HDPE dan pati lebih diperkuat sehingga komposit HDPE menjadi kurang elastis. Penurunan sifat komposit plastik ini juga dapat disebabkan rusaknya ikatan sekunder pada molekul HDPE. Hasil penelitian ini juga didukung oleh penelitian yang dilakukan oleh $\mathrm{Pg}$ Adnan \& Arshad (2017), yang menyatakan bahwa perlakuan panas lebih lanjut menurunkan sifat perpanjangan putus dari komposit pati tapioka yang diisi dengan abu sekam padi.

Pengaruh jumlah pati tapioka terhadap densitas komposit HDPE disajikan pada Gambar 3. Gambar 3 memperlihatkan densitas komposit HDPE meningkat dengan meningkatnya jumlah pati tapioka yang ditambahkan. Hal tersebut dikarenakan semakin banyak bahan aditif yang mempunyai densitas lebih tinggi dari HDPE yang ditambahkan dalam suatu matriks polimer, maka berat dan kerapatan polimer semakin tinggi, sehingga densitas menjadi tinggi. Seperti diketahui bahan aditif terbesar di dalam komposit ini mempunyai densitas yang lebih besar dari plastik HDPE, seperti pati tapioka mempunyai densitas sekitar $1,5 \mathrm{~g} / \mathrm{cm}^{3}$, gliserol memiliki densitas $1,26 \mathrm{~g} / \mathrm{cm}^{3}$ sedangkan densitas HDPE $0,95 \mathrm{~g} / \mathrm{cm}^{3}$. Hasil yang sama juga diperoleh Roy et al. (2015) yang menyatakan bahwa nilai densitas meningkat dengan meningkatnya kandungan pati.

\section{Analisis Difraktogram XRD}

Difraksi sinar-X dapat digunakan untuk mengidentifikasi struktur kristal dan pengaturan molekuler teratur pati. Pola difraksi komposit

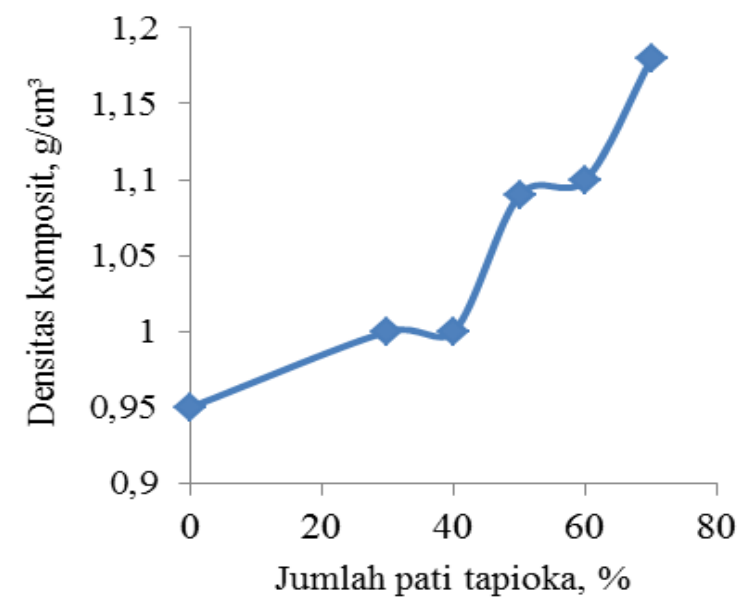

Gambar 3. Pengaruh jumlah pati tapioka terhadap densitas komposit HDPE.
HDPE yang berisi tepung tapioka pada berbagai jumlah disajikan pada Gambar 4.

Menurut Chouit et al. (2014) HDPE memiliki dua puncak utama pada 2-theta $=21,6^{\circ}$ dan $24,0^{\circ}$ yang mencerminkan sel satuan ortorombik, tetapi ketika diproses menjadi komposit dengan penambahan pati tapioka $30 \%$, tiga puncak utama komposit HDPE muncul pada 2-theta $=19,90^{\circ} ; 21.61^{\circ}$ dan $24,02^{\circ}$ dengan intensitas berturut-turut 716(77) cps, 3417(169) cps dan 1803(123) cps (Gambar 4a). Penambahan pati tapioka 50\% menunjukkan pola campuran dengan tiga puncak utama pada 2-theta $=12,49^{\circ} ; 21,95^{\circ}$, dan $24,36^{\circ}$ dengan intensitas berturut-turut 100(29) cps, 2493(144) cps, 1426(109) cps (Gambar 4b).

Penggabungan pati singkong ke HDPE menggeser posisi 2-theta dari $19,90^{\circ}$ ke $12,49^{\circ}$. Penambahan pati tapioka $70 \%$ menunjukkan pola campuran dengan dua puncak utama pada 2-theta $=21.72^{\circ}$ dan $23.56^{\circ}$ dengan intensitas berturut-turut $967277 \mathrm{cps}$ dan $1044.66 \mathrm{cps}$ serta tidak munculnya posisi 2-theta $19,9^{\circ}$ (Gambar 4c) yang berarti terjadi penurunan kristalinitas. Dari Gambar 4 terlihat bahwa dengan penambahan pati tapioka terjadi pergeseran nilai 2-theta dan penurunan intensitasnya. Gambar 4 juga memperlihatkan bahwa komponen HDPE yang menyebabkan intensitas puncak utama dalam difraktogram, meskipun komponen HDPE dimasukkan ke dalam komposit lebih sedikit dibanding dengan pati tapioka (Gambar 4c). Hal ini juga sama dengan yang ditemukan oleh

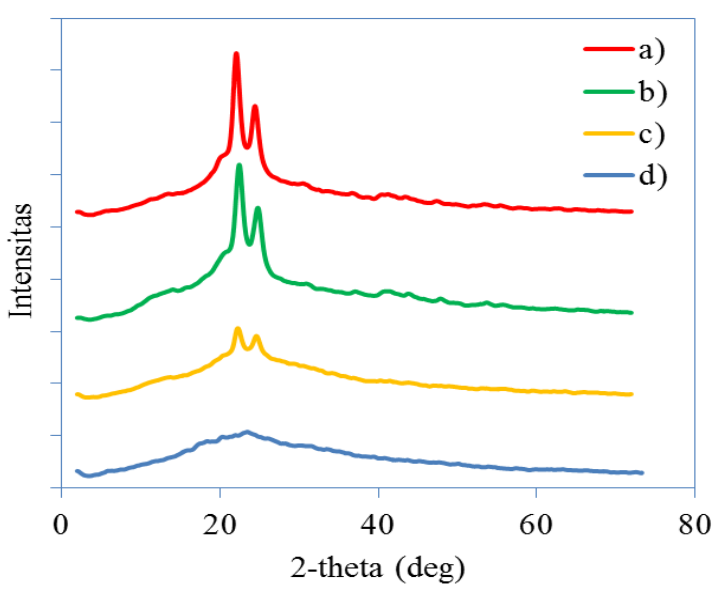

Gambar 4. Difraktogram XRD dari komposit HDPE pada berbagai jumlah pati tapioka (a. $30 \%$, b. $50 \%$, c. $70 \%$ ), dan pati tapioka yang berisi bahan aditif (d). 
Tanetrungroj \& Prachayawarakorn (2015). Pati tapioka murni merupakan material yang mempunyai struktur semi kristalin dan struktur kristalin pati akan rusak pada saat gelatinisasi. Menurut Lomeli-Ramirez et al. (2014) pati tapioka mempunyai 5 puncak utama pada 2-theta $=15,2^{\circ} ; 17,2^{\circ}, 18,1^{\circ} ; 20,1^{\circ}$ dan $23,1^{\circ}$ sedangkan pada Gambar 4d terlihat bahwa pati tapioka yang berisi bahan aditif (gliserol, air dan asam asetat) memperlihatkan karakteristik amorf karena mungkin sebagian struktur kristalin pati telah rusak tetapi terdapat kecenderungan untuk puncak kristal pada 2-theta $=22,70^{\circ}$.

\section{Karakterisasi FTIR}

Spektroskopi FTIR merupakan suatu metode analisis yang dipakai untuk karakterisasi bahan polimer dan analisis gugus fungsi. Gambar 5 menunjukkan spektrum FTIR dari komposit HDPE yang berisi pati tapioka 30\%, 50\% dan $70 \%$ (Gambar 5a, b dan c), pati yang berisi aditif (Gambar 5d) dan HDPE murni (Gambar 5e). Gambar 5d menunjukkan pita absorpsi yang sesuai dengan gugus fungsi pati dan gliserol, yaitu adanya puncak yang luas dan kuat di daerah $3282,36 \mathrm{~cm}^{-1}$ (regangan $\mathrm{OH}$ ), pita serapan pada $2914 \mathrm{~cm}^{-1}$ (regangan $\mathrm{CH}$ ), $1648 \mathrm{~cm}^{-1}$ (air yang terserap) dan juga pita serapan pada daerah 1335,$96 ; 1149,47$; 1076,70; 995,91 ; dan 924,55 $\mathrm{cm}^{-1}$.

Menurut hasil penelitian Deeyai et al. (2013) menyatakan pita serapan $1336 \mathrm{~cm}^{-1}$ diidentifikasi sebagai tekuk $\mathrm{C}-\mathrm{O}-\mathrm{H}$, pelintiran $\mathrm{CH}_{2}$, pita serapan $1149 \mathrm{~cm}^{-1}$ diidentifikasi sebagai ikatan glikosidik regangan asimetri $\mathrm{C}-\mathrm{O}-\mathrm{C}, 1078 \mathrm{~cm}^{-1}$ adalah $\mathrm{C}-\mathrm{O}, \mathrm{C}-\mathrm{C}$ dan regangan $\mathrm{O}-\mathrm{H}, 1043 \mathrm{~cm}^{-1}$ adalah tekuk $\mathrm{C}-\mathrm{O}-\mathrm{H}$ (pembentukan heliks), $1016 \mathrm{~cm}^{-1}$ merupakan $\mathrm{C}-\mathrm{O}$, regangan $\mathrm{C}-\mathrm{C}$, tekuk C-O-H, $993 \mathrm{~cm}^{-1}$ tekuk C-O-H, $924 \mathrm{~cm}^{-1}$ adalah $\mathrm{C}-\mathrm{O}-\mathrm{C}$ (ikatan $\alpha$-glycosidic).

Menurut Lomeli-Ramirez et al. (2014) pita serapan diantara 1400 dan $900 \mathrm{~cm}^{-1}$ adalah vibrasi $\mathrm{C}-\mathrm{O}$ dari alkohol atau kelompok eter dari gliserol dan pati karbohidrat dalam campuran. Untuk FTIR HDPE murni (Gambar 5e) menunjukkan puncak serapan kuat pada daerah $2914,21 \mathrm{~cm}^{-1}$ dan $2846,69 \mathrm{~cm}^{-1}$ masing-masing menunjukkan vibrasi regangan $\mathrm{C}-\mathrm{H}$ asimetris dan simetris, puncak tajam pada 1472,23 $\mathrm{cm}^{-1}$ dan $1461,75 \mathrm{~cm}^{-1}$ (vibrasi tekuk $\mathrm{CH}_{2}$ ), puncak ganda di 729,97 $\mathrm{cm}^{-1}$ dan $718,66 \mathrm{~cm}^{-1}$ (goyangan $\mathrm{CH}_{2}$ ). Hasil penelitian Jung et al. (2018), ATR FTIR dari HDPE memperlihatkan pita serapan pada panjang gelombang $2915 \mathrm{~cm}^{-1}$ (regangan
$\mathrm{CH}), 2845 \mathrm{~cm}^{-1}$ (regangan $\mathrm{CH}$ ), $1472 \mathrm{~cm}^{-1}$ (tekuk $\mathrm{CH}_{2}$ ), $1462 \mathrm{~cm}^{-1}$ (tekuk $\mathrm{CH}_{2}$ ), $730 \mathrm{~cm}^{-1}$ (goyangan $\mathrm{CH}_{2}$ ) dan $717 \mathrm{~cm}^{-1}$ (goyangan $\mathrm{CH}_{2}$ ).

Spektrum FTIR dari komposit HDPE yang berisi pati tapioka, semua puncak karakteristik

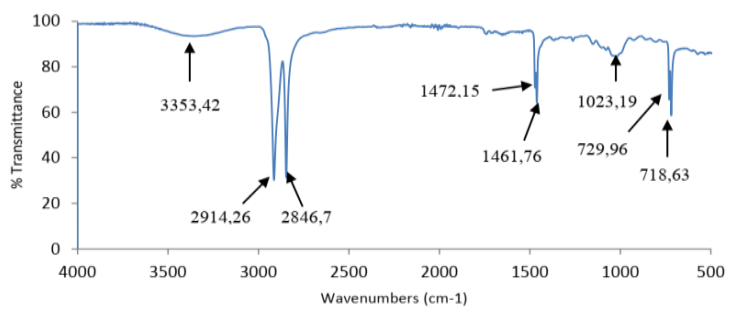

(a)

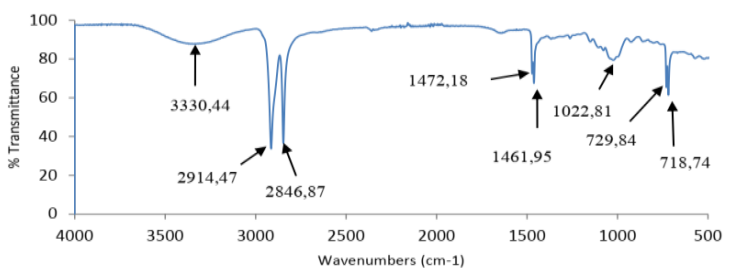

(b)

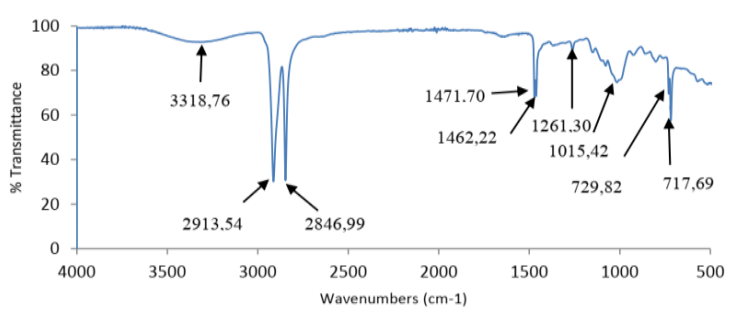

(c)

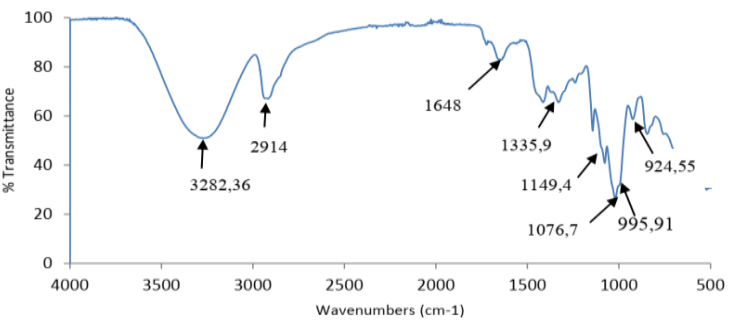

(d)

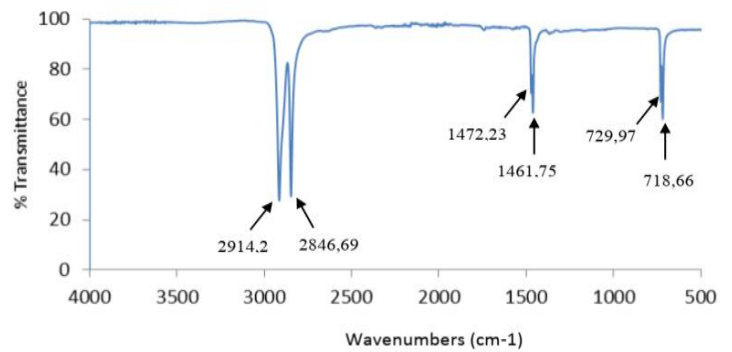

(e)

Gambar 5. Spektrum FTIR komposit HDPE pada berbagai jumlah pati tapioka (a. 30\%, b. $50 \%$, c. $70 \%$ ), pati tapioka berisi aditif (d), HDPE (e). 
milik HDPE terlihat, namun untuk puncak serapan pati tapioka yang berisi aditif ada beberapa puncak serapan yang hilang pada daerah $1648 \mathrm{~cm}^{-1}$ yaitu air yang terserap yang hilang pada saat proses pencampuran dengan panas, selain itu juga serapan di daerah 1076,70 $\mathrm{cm}^{-1}$ (tekuk C-O-H), dan 1335,96 $\mathrm{cm}^{-1}$ (kibasan $\mathrm{CH}_{2}$ ). Serapan pada daerah 995,91-924,55 $\mathrm{cm}^{-1}$ dan didukung serapan pada daerah $1149,47 \mathrm{~cm}^{-1}$ yang merupakan ikatan glikosida $\mathrm{C}-\mathrm{O}-\mathrm{C}$ sedikit bergeser menjadi serapan di daerah $1023,19 \mathrm{~cm}^{-1}$ (untuk kandungan pati 30\%); 1022,81 $\mathrm{cm}^{-1}$ (untuk kandungan pati 50\%); dan 1015,42 $\mathrm{cm}^{-1}$ (untuk kandungan pati 70\%). Pergeseran panjang gelombang ini mungkin terjadinya transisi amorf-kristal. Bukti ini juga diperkuat dari hasil uji XRD untuk komposit yang berisi pati tapioka $70 \%$ muncul pita serapan $1261,30 \mathrm{~cm}^{-1}$ yang menurut Lomeli-Ramirez et al. (2014) mungkin merupakan rantai samping dari grup $\mathrm{CH}_{2}-\mathrm{OH}$.

\section{KESIMPULAN}

Penambahan pati tapioka yang telah diberi plasticizer menurunkan sifat kuat tarik dan meningkatkan nilai perpanjangan putus komposit HDPE. Perlakuan aging pada suhu $70^{\circ} \mathrm{C} \pm 2^{\circ} \mathrm{C}$ selama 168 jam \pm 2 jam untuk penambahan pati tapioka $\geq 50 \%$ terjadi kenaikan sifat kuat tarik namun perlakuan aging ini menurunkan sifat perpanjangan putus komposit. Densitas komposit HDPE meningkat dengan meningkatnya jumlah pati tapioka yang ditambahkan. Difraktogram XRD komposit HDPE memperlihatkan bahwa penambahan pati tapioka menyebabkan terjadinya pergeseran nilai 2-theta dan penurunan intesitasnya walaupun terlihat bahwa komponen HDPE yang menyebabkan intensitas puncak utama dalam difraktogram. Spektra FTIR komposit HDPE yang berisi berbagai jumlah pati tapioka memperlihatkan pergeseran panjang gelombang dari pati tapioka yang berisi aditif yang mungkin terjadinya transisi amorf-kristal.

\section{UCAPAN TERIMA KASIH}

Penulis mengucapkan terima kasih kepada Kepala Balai Besar Kulit, Karet dan Plastik yang telah memberi kepercayaan untuk melakukan penelitian dan kepada Tim Kelompok Kerja 1866.001.001.052D tahun 2017 yang telah membantu penelitian ini sampai selesai.

\section{DAFTAR PUSTAKA}

Adamu, A. D., Jikan, S. S., Talip, B. H. A., Badarulzaman, N. A., \& Yahaya, S. (2017).
Effect of glycerol on the properties of tapioca starch film. Materials Science Forum, 888, 239243.

https://doi.org/10.4028/www.scientific.net/MSF. $\underline{888.239}$

Ali, R. R., Rahman, W. A. W. A., Kasmani, R. M., Ibrahim, N., Mustapha, S. N. H., \& Hasbullah, H. (2013). Tapioca starch biocomposite for disposable packaging ware. Chemical Engineering Transactions, 32, 1711-1716. https://doi.org/10.3303/CET1332286

Chouit, F., Guellati, O., Boukhezar, S., Harat, A., Guerioune, M., \& Badi, N. (2014). Synthesis and characterization of HDPE/N-MWNT nanocomposite films. Nanoscale Research Letters, 9, 288-293. https://doi.org/10.1186/1556276X-9-288

Deeyai, P., Suphantharika, M., Wongsagonsup, R., Dangtip, S. (2013). Characterization of modified tapioca starch in atmospheric argon plasma under diverse humidity by FTIR spectroscopy. Chinese Physics Letters, 30(1), 0181031. https://doi.org/10.1088/0256-307X/30/1/018103

Jung, M. R., Horgen, F. D., Orski, S. V., Rodriguez C, V., Beers, K. L., Balazs, G. H., Jones, T. T., Work, T. M., Brignac, K. C., Royer, S., Hyrenbach, K. D., Jensen, B. A., \& Lynch, J. M. (2018). Validation of ATR FT-IR to identify polymers of plastic marine debris, including those ingested by marine organisms. Marine Pollution Bulletin, 127, 704-716. https://doi.org/10.1016/j.marpolbul.2017.12.061

Lomelí-Ramirez, M. G., Kestur, S. G., ManríquezGonzález, R., Iwakiri, S., Bolzon, M. G., de Muniz, G. B., \& Flores-Sahagun, T. S. (2014). Bio-composites of cassava starch-green coconut fiber: Part II-Structure and properties. Carbohydrate Polymers, 102, 576-583. https://doi.org/10.1016/j.carbpol.2013.11.020

Lutfi, M., Sumarlan, S. H., Susilo, B., Wignyanto, Zenata, R., \& Perdana, L. P. R. (2017). The glycerol effect on mechanical behaviour of biodegradable plastic from the Walur (Amorphophallus paenifolius var. sylvestris). Nature Environment and Pollution Technology, 16(4), 1121-1124.

Maran, J. P., Sivakumar, V., Thirugnanasambandham, K., \& Sridhar, R. (2014). Degradation behaviour of biocomposites based on cassava starch buried under indoor compost conditions. Carbohydrate Polymers, 101, 20-28. https://doi.org/10.1016/j.carbpol.2013.08.080

Mendes, J. F., Paschoalin R. T., Carmona V. B., Neto, A. R. S., Marques, A. C. P., Marconcini, J. M., Mattoso, L. H. C., Medeiros, E. S., \& Oliveira, J. E. (2016). Biodegradable polymer blends based on corn starch and thermoplastic chitosan processed by extrusion. Carbohydrate Polymers, 
137 ,

452-458. https://doi.org/10.1016/j.carbpol.2015.10.093

Nguyen, D. M., Do, T. V. V., Grillet, A., Thuc, H. H., \& Thuc, C. N. H. (2016). Biodegradability of polymer film based on low density polyethylene and cassava starch. International Biodeterioration \& Biodegradation, 115, 257265. https:// doi.org/10.1016/j.ibiod.2016.09.004

Obasi, H. C., \& Igwe, I. O. (2014). Effects of native cassava starch and compatibilizer on biodegradable and tensile properties of polypropylene. American Journal of Engineering Research, 3(2), 96-104.

Oragwu, I. P. (2016). Investigations on the cornstarch modified low density polyethylene blends. Matter: International Journal of Science and Technology, 2(1), 01-11. https://doi.org/10.20319/mijst.2016.21.0111

Pg Adnan, D. N., \& Arshad, S. E. (2017). Effect of thermal treatment on mechanical properties rice husk ash filled tapioca starch composite. Transactions on Science and Technology, 4(3-2), 286-291.

Prabha, P. H., \& Ranganathan, T. V. (2017). Modelling and optimization of cassava starch based film for food packaging applications. Pakistan Journal of Biotechnology, 14(4), 571586.

Roy, S. B., Shit, S. C., Sengupta, R. A., \& Shukla, P. R. (2015). Studies on biodegradability, morphology, physicomechanical and thermal properties of $\mathrm{PP} /$ potato starch bio-composite. International Journal of Current Engineering and Technology, 5(2), 1074-1084.

Sabetzadeh, M., Bagheri, R., \& Masoomi, M. (2015). Study on ternary low density polyethylene/linear low density polyethylene/thermoplastic starch blend films. Carbohydrate Polymers, 119, 126133. https://doi.org/10.1016/j.carbpol.2014.11.038
Samper-Madrigal, M. D., Fenollar, O., Dominici, F., Balart, R., \& Kenny, J. M. (2015). The effect of sepiolite on the compatibilization of polyethylene-thermoplastic starch blends for environmentally friendly films. Journal of Materials Science, 50(2), 863-872. https://doi.org/10.1007/s10853-014-8647-8

Sanyang, M. L., Sapuan, S. M., Jawaid, M., Ishak, M. R., \& Sahari, J. (2016). Effect of plasticizer type and concentration on physical properties of biodegradable films based on sugar palm (Arenga pinnata) starch for food packaging. Journal of Food Science and Technology, 53(1), 326-336. https://doi.org/10.1007/s13197-015-2009-7

Tajeddin, B., \& Abdulah, L. C. (2010). Thermal properties of high density polyethylene-kenaf cellulose composites. Polymers and Polymer Composites, 18(5), 257-261. https://doi.org/10.1177/096739111001800503

Tanetrungroj, Y., \& Prachayawarakorn, J. (2015). Effect of starch types on properties of biodegradable polymer based on thermoplastic starch process by injection molding technique. Songklanakarin Journal of Science and Technology, 37(2), 193-199.

Yamak, H. B. (2016). Thermal, mechanical and water resistance properties of LDPE/starch bio-based polymer blends for food packing applications. Journal of the Turkish Chemical Society, Section A: $\quad$ Chemistry, 3(3), 637-656. http://doi.org/10.18596/jotcsa.287300

Zanela, J., Casagrande, M., Shirai, M. A., de Lima, V. A., \& Yamashita, F. (2016). Biodegradable blends of starch/polyvinyl alcohol/glycerol: Multivariate analysis of the mechanical properties. Polimeros, 26(3), 193-196. https://doi.org/10.1590/0104-1428.2420 
